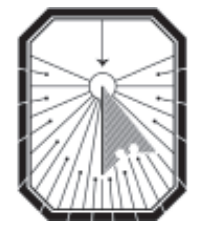

KYIV-MOHYLA

HuMANiTiES JOURNAL

KYIY-MOHYLA SCHOLARLY PEER-REVIEWED JOURNALS

\title{
Lesia Ukrainka in Cinema
}

Author(s): Oksana S. Moussienko, Natalia Moussienko, Oksana O. Moussienko

Source: Kyiv-Mohyla Humanities Journal 8 (2021): 184-193

Published by: National University of Kyiv-Mohyla Academy

http://kmhj.ukma.edu.ua/ 


\title{
Lesia Ukrainka in Cinema
}

\author{
Oksana S. Moussienko \\ National Academy of Arts of Ukraine
}

\author{
Natalia Moussienko \\ Modern Art Research Institute of the National Academy of Arts of Ukraine
}

Oksana O. Moussienko

Kyiv National I.K. Karpenko-Kary Theater, Cinema, and Television University

\section{讨}

Prominent personalities have attracted the attention of cinema almost from the beginning of the art form, with biopics being produced by popular entertainers and avant-garde artists alike. In the 1920s, the heyday of silent film, for example, two movies about Joan of Arc were shot in France. One was a historical action film with large-scale battle scenes, while the other, La passion de Jeanne d'Arc, was a philosophical tragedy directed by Carl Theodor Dreyer. Well-known avant-garde director Abel Hans created the epic Napoleon, where the artist used the widest arsenal of expressive means of the screen.

Ukrainian national icon, poet, and artist Taras Shevchenko, has also been given the biopic treatment many times in cinema. The first film about him came out in 1926, when Petro Chardynin, one of the most experienced directors of the period, put Shevchenko's life to film at the Odesa Film Studio, the starring role played by Amvrosii Buchma.

The range of biographical cinema started expanding worldwide with the advent of sound, which increased the possibility of penetrating the psychology of characters, the trend becoming fully manifest in the 1930s. Leading Hollywood director and German émigre William Dieterle produced biopics dedicated to Emile Zola, Louis Pasteur, Rembrandt van Rijn, and others.

Biographical films were also very popular in the Soviet Union of the 1930s, the country's leadership being well aware of the propaganda potential of biopics. Preference was given to historical figures, the interpretation of their roles in history changing depending on the cultural policy of the Kremlin. For instance, Tsar Peter I was at first portrayed as a class enemy but later in the decade emerged as a progressive historical figure.

The peak period for biopics came in the early postwar period. At the time, Communist Party censorship was particularly severe, resulting in the growth of a number of biographical films about correct historical figures, cultural and intellectual, as well as famous military leaders. 
Renowned directors like Oleksandr Dovzhenko, Vsevolod Pudovkin, Mikhail Romm, and Grigori Kozintsev all worked on such films. However, most of these men quickly met with creative defeats. Texts that demonstrated a good knowledge of Marxist theory were to be voiced by famous individuals, whether it was Admiral Ushakov, the composer Modest Mussorgsky, or the inventor of radio, Alexander Popov.

Films about artists ended up being the most contrived, since screenwriters were required to squeeze into a two-hour film the entire biography of some famous person.

Eisenstein proposed an innovative way of telling the story of Russian poet Alexander Pushkin. Together with well-known literary critic and writer Yurii Tynianov, the director began working on the script for a film entitled Liubov poeta (The Love of a Poet) of which, unfortunately, only a draft remains. The artists focused on the myth of the poet's secret love for Katerina Karamzina. For Eisenstein, the myth was "true and important not because of the facts, but because of its emotional and ethical conviction." It can be argued that the poet's own life was reflected through his work.

In Ukrainian cinema, this approach was used very efficiently. In the 1960s and 1970s, along with traditional biographical movies shot for anniversaries, there appeared a number of films that revealed some other aspects of the artists' lives.

For instance, in 1964, director Volodymyr Denysenko released Son (The Dream), where for the first time Taras Shevchenko was presented beyond his textbook image, from which another well-known director, Ihor Savchenko, was not allowed to deviate in his 1951 biopic. The pressure of Stalin's censorship was too strong at the time.

Scriptwriters Denysenko and Dmytro Pavlychko created the film as a system of retrospectives, where the imaginary (memories, poetic fantasies) intersects with real events from the poet's life.

Another example of the screen potential of a literary work can be found in Sergei Paradzhanov's masterpiece Tini zabutyh predkiv (Shadows of Forgotten Ancestors), based on a Mykhailo Kotsiubynskyi story.

As 1971 approached, Ukraine's Communist Party leadership decided to celebrate the centenary of the birth of Ukrainian poetess and dramatist Lesia Ukrainka (born Larysa Kosach). She was always considered a progressive poet by Soviet authorities, her works being included in school curricula, and her ideological proximity to socialdemocratic ideas was emphasized in every possible way. At the same time, her biographers tried not to focus on the awkward moments of her life or delve too deeply into interpretations of her philosophical dramas. In her poetry, one could find many things that would not correspond to her textbook image.

Lesia Ukrainka's most popular drama-extravaganza Lisova pisnia (The Forest Song) was first filmed in 1962. Then, the decision was made to produce a biographical film for the poetess' birth centenary. Since this was the heyday of poetic cinema, screenwriters no longer had to follow the path of established hagiography. Ivan Drach, one of the brightest figures of the Ukrainian 196os generation, was selected to write the 
script. He was not just a celebrated poet, but also a professional screenwriter. By that time, he had written the scripts of such films as Krynytsia dlia sprahlykh (1965; A Well for the Thirsty) by Yurii Illienko and Kaminnyi khrest (1968; The Stone Cross) by Leonid Osyka.

Even though the script was commissioned for the anniversary, its path to the screen met with many obstacles. The screenwriter abandoned the set forms of Soviet biographical filmmaking and took for the heart of the plot one of the most dramatic episodes in the poet's life. In the winter of 1900, Lesia Ukrainka traveled to Minsk, the capital of today's Belarus, where she held a bedside vigil for her dying friend Serhii Merzhynskyi. On one of the most trying nights, she wrote her philosophical drama Oderzhyma (1901; A Woman Possessed). As she recalled later, this work became her personal salvation at the moment of her deepest and darkest despair.

The team invited Rolan Serhiienko to direct. After a thorough search for an actress to play the role of Lesia Ukrainka, the director settled on Irina Kupchenko, then a popular Russian actress of Ukrainian origin, whose psychophysical traits, bearing a certain resemblance to Lesia Ukrainka's, corresponded to the lyrical interpretation of the protagonist of the film. However, party officials soon removed Serhiienko from the film and advised the director not to have contact with the unreliable and unpredictable Ivan Drach. ${ }^{2}$ Serhiienko later said that this was his personal tragedy. ${ }^{3}$ The director was especially upset because he and Drach were like-minded and had been friends for many years.

Yurii Lysenko was the next director chosen to work on the script. He offered the role of Lesia Ukrainka to ballerina Eleonora Stebliak. His choice was based on her close visual resemblance to the poetess. But an external likeness was not enough. Test screen footage revealed that the performer could not cope with the tasks set by the director.

In search of a way out of the impasse, management appointed a third director: Mykola Mashchenko. Drach's script was much appreciated by him, as it had practically no external action. Instead, emphasis was placed on the spiritual world of the main characters, and there were only two: Lesia Ukrainka and Serhii Merzhynskyi.

Mykola Mashchenko did not have a lead actress when he began work, but the popular Moscow Taganka Theater was touring Kyiv at that time. Alla Demidova, an actress who had already had a few film roles, was a member of the troupe, and the screenwriter mentioned that he was impressed with her talent, spirituality, and intellect. Demidova's Lesia Ukrainka is a poetess of genius, an intellectual, and also a woman in love, who witnesses the tragic end of her beloved.

The film received mostly positive reviews from critics, although it had a modest screen life. The well-known Polish critic and film theorist Janusz Gazda described Mashchenko's film as a kind of 
masterfully executed mosaic in which words and images are organically intertwined... The screen image is almost exclusively presented in chamber, it does not attempt to illustrate Lesia Ukrainka's poetry with elaborate staging. Emotion is reproduced primarily in deliberate small gestures, movements, and contemplative looks. The film is rich in close-ups of faces, hands, and details. All of this is organized via a montage of the subject in pulse with a poetic rhythm. Images flow like words in a poem. ${ }^{4}$

The critic concluded that the film "was an important milestone in the life of Ukraine."5

The country's party leadership, however, met the release of Mashchenko's film with devastating criticism. "The Report of the Department of Culture of the Central Committee of the Communist Party of Ukraine on Some Members of the Writers' Union of Ukraine," dated December 18, 1973, stated that Ivan Drach's script was marked by serious ideological and artistic shortcomings and that there was much overspending of public funds. And also that the film in general "did not successfully deal with some of the shortcomings of the script: Lesia Ukrainka is portrayed in one dimension outside her activities as a representative of the revolutionary-democratic movement, the national moment being somewhat exaggerated."

Mashchenko's film should not be considered from a historical perspective alone. After all, Lesia Ukrainka is not a frozen academic figure of Ukrainian culture. This is argued in Apokryph (Apocryphon), a recent monograph, through a dialogue between Sviatoslav Shevchuk, major archbishop of the Ukrainian Greek-Catholic Church, and prominent writer Oksana Zabuzhko. Zabuzhko is the author of one of the best known studies of the life and works of the poetess Notre Dame d'Ukraine: Ukrainka v konflikti mifolohiy (2007; Notre Dame d'Ukraine: Ukrainka in a Conflict of Mythologies). ${ }^{7}$

Zabuzhko's research delves into the dialectical unity of the poetess' personal life and writings. She is critical of Mashchenko's film because, from her point of view, the plot is based on a watered-down story of the relationship between Ukrainka and Merzhynskyi, portrayed as a melodramatic love triangle. She loves him, but he loves someone else. ${ }^{8}$ There was even a kind of trapezoid, Zabuzhko jokes, mentioning Pavlo

$4 \quad$ Briukhovetska, Poetychne kino, 117

5 Proekt Pleiada, "Na ekranah pokazhut serial pro ukrainskykh hipsteriv [Pleiades TV series. TV screens Will Show a Series About Ukrainian Hipsters]," UA:Radio, accessed December 7, 2021, http://ukr.radio/news.html?newsID=91377.

6 "Nevzhe tse bulo neshchodavno? Pro deiaki partiini dokumenty 6o-7o rokiv [Was it Really Not That Long Ago? On Some Party Documents of the 1960s and 1970s]," Memorial.kiev.ua, accessed December 7, 2021, https://web.archive.org/ web/2006051807490o/http://memorial.kiev.ua/content/view/78/30. Oksana Zabuzhko, Notre Dame D’Ukraine: Ukrainka v konflikti mifolohiy [Norte Dame D'Ukraine: Ukrainka in a Conflict of Mythologies] (Kyiv: Fakt, 2007). Zabuzhko, Notre Dame d'Ukraine, 101. 
Tuchapskyi, the husband of Vira Kryzhanivska. Defending her point of view, the scholar argues that the relationship between Ukrainka and Merzhynskyi occurred on a completely different plane, which is confirmed in various writings of the poetess.

Lesia Ukrainka's poem in prose addressed to Merzhynskyi, who was already seriously ill, is a case in point: "Your Letters Always Smell of Withered Roses..." This extremely personal text allows to reveal the relationship between Ukrainka and Merzhynskyi.

It's nothing that you never embraced me, it's nothing that there is no memory of kisses between us, oh, I'll come to you from the tightest embraces, from the sweetest kisses! Only with you I am not alone, only with you I am not a stranger. Only you know how to save me from myself. ${ }^{9}$

These words do not belong to an unloved woman. They convincingly show the spiritual connection that united the two in a tragic existential situation.

The poetess had to endure conflict in her life, which served as the basis for her poetic discourse. The eternal opposition of Heavenly Love and Earthly Love would become the main theme running through the works of Lesia Ukrainka. This opposition first began in the author's verse and in her first play, Blakytna troianda (The Blue Rose), and would become most fully expressed in Oderzhyma. Zabuzhko argues that the mature Lesia Ukrainka begins with Oderzhyma.$^{10}$ And while Blakytna troianda contains autobiographical elements, Oderzhyma can be regarded as a spiritual biography of the writer, a sublimation of her worries and salvation upon facing the death of a loved one.

Lesia Ukrainka wrote about this in a long letter to fellow Ukrainian writer Ivan Franko almost two years after those tragic events in her life. He replied that in Oderzhyma, the "epic tone is not sustained" and that "even the drama is lyrical," compelling the poetess to reveal the painfully personal nature of the dramatic poem.

If we are being honest right now, I must admit that I wrote it during a night after which I will probably live for a long time, if I manage to stay alive. And I even wrote it without digesting longing, but rather at its peak. If someone would ask me how I came out of it alive, I could answer them: J'en ai fait une drame... ${ }^{12}$

Oderzhyma represented one of the most crucial moments of Lesia Ukrainka's biography as an artist and as a person. Thus, it made sense for Drach to introduce the

9 Lesia Ukrainka, Zibrannia tvoriv [Collected Works], vol. 1 (Kyiv: Naukova Dumka, 1977), 257.

$10 \quad$ Zabuzhko, Notre Dame d'Ukraine, 94.

11 Lesia Ukrainka, Zibrannia tvoriv [Collected Works], vol. 12 (Kyiv: Naukova Dumka, 1977), 18.

12 Ukrainka, Zibrannia tvoriv, vol. 12, 18. 
dramatic poem into the body of his script, drawing logical parallels between it and the life of the poetess.

Mashchenko's film embued the script with many hidden meanings that can only be seen on screen. The director's unique style developed as he progressed on the film. First of all, maximum attention was given to the faces of the heroes, as the smallest nuances of expression informed the audience more than expansive dialogues. Mashchenko created a drama on screen through "portrait shots." And although the work is full of both monologue-confessions and dialogues between the heroes, the main content is revealed via the image.

Alla Demidova, the lead in the film, had previously created impressivly rich and varied characters on the stage. Both critics and theater director Yurii Liubimov thought the actres was too intelligent, and therefore cold and reserved. However, there had always been a riot of passions inside of her, like magma under cold volcanic ash.

This is exactly how Larysa Kosach (Lesia Ukrainka) appeared in Mykola Mashchenko's film. In moments of despair, addressing her dying lover, the poetess would write such sad lines as: "Take me away with you..." But at the same time and with extraordinary firmness she would testify that she was ready to end his suffering with a fatal morphine injection.

Mashchenko's film also contains a revolutionary theme. This is no surprise because no biographical film about prominent figures of the past could do without these references. As Zabuzhko remarked, to be a classic in that culture, in a sense, meant to be an eternal secretary of ideology regarding the dead, and the main function of historians of philosophy, literature, art, etc. was to provide the prominent deceased with "production specifications."

However, there is no use in pretending that Lesia Ukrainka was not in contact with socialists. This really happened, and Merzhynskyi also belonged to this circle. And yet, the poet never became an orthodox Marxist, remaining critical of this ideology. She did not see in the fundamental work of Marx "the strict system of which the fanatics of this book speak." ${ }^{14}$ To the contrary, Lesi Ukrainka saw in the text of Das Capital much that was "dark, unexplained, and absolute, both in its scientific theory and in its practical conclusions." ${ }^{15}$

The next film based on the work of the poetess was made a decade later, in 1981. It was an adaptation of the play, Lisova pisnia (The Forest Song). The film was directed by one of the most consequential representatives of the poetic school of Ukrainian cinema, Yurii Illienko. He adapted Lesia Ukrainka's text and worked as both director of photography and director.

The film was received coolly by critics and audiences alike. This bothered the director, but he later admitted in an interview that those years were a period of lost

Zabuzhko, Notre Dame d'Ukraine, 97.

14 Lesia Ukrainka, Zibrannia tvoriv [Collected Works], vol. 10 (Kyiv: Naukova Dumka, 1977), 181.

15 Ukrainka, Zibrannia tvoriv, vol. 10, 181. 
opportunities. "I made a film called The Forest Song. Mavka. It was an adaptation from Lesia Ukrainka, where life could be discussed using conditional language. It is no more than a minor episode of my biography."16

And yet, this film should not be ignored. The camera shows us an image of nature just like we would perceive it in Lesia Ukrainka's poetry.

Asking actor Ivan Mykolaichuk to play two roles - Uncle Lev and the Forest Elf was an effective cinematic decision. The characters appear as a duality of one person. By betraying the Forest Elf and breaking his promise to this spirit of the forest, Lev betrays himself, and his inner world. And so, having lost his connection with the spirit of nature, becoming a slave to natura vulgaris, he is unable to prevent the catastrophe that befalls him and his neighbors. Larysa Briukhovetska notes: “This role in Illienko's film is played in the noblest way... the wise and calm grandfather Lev is perhaps the most vivid figure, and it is a pity that he remains on the periphery of the film and is not able to influence the main character." ${ }^{17}$

It can be argued that Uncle Lev's compromise was in line with the compromises artists had to make during the dark times of stagnation of the Brezhnev years. Illienko spoke about this with genuine pain, revealing the insidious mechanisms of party bureaucracy in the "art of entangling artists in their devilish webs." 18

Kaminnyi Hospodar (The Stone Host), one of the last dramatic works of the poetess, is also a tragedy of compromise. This original version of the Don Juan legend was not only its first interpretation in Ukrainian literature, it was also written by a woman, which Ukrainka considered to be a personal victory.

Lesia Ukrainka shared her thoughts about the just-completed drama with her closest friend, Olha Kobylianska. She wrote that she was sure that Olha would understand all her doubts about the characters and their interpretation. The poetess admitted that she followed tradition in describing the protagonist, with the exception of emphasizing the anarchy of his character. Donna Anna, according to Lesia Ukrainka, took up "too much space in the drama, much more than was originally intended."19 She self-critically remarked that she failed to "describe Dolores so that she would not pale in comparison to Anna." ${ }^{20}$ At the same time, the poetess admitted that this is just how it is, that "people like Dolores must remain in the shadow of people like Anna." ${ }^{21}$ And yet, those set ways of life to which the proud Donna Anna eventually succumbed, followed by the freedom-loving Don Juan, have no power over the tender and free soul of Dolores. The letter to Kobylianska ends with a confession that she was in a hurry because she feared that the drama might remain unfinished due to her poor health.

\footnotetext{
16 Briukhovetska, Poetychne kino, 382.

17 Briukhovetska, Poetychne kino, 416.

18 Briukhovetska, Poetychne kino, 379.

19 Ukrainka, Zibrannia tvoriv, vol. 12, 462.

20 Ukrainka, Zibrannia tvoriv, vol. 12, 462.

21 Ukrainka, Zibrannia tvoriv, vol. 12, 462.
} 
Ukrainian cinematographers did not ignore Lesia Ukrainka's reading of the legend. In 1971, the play was brought to the screen at Ukrtelefilm by Myroslav Dzhyndzhyrystyi. His film did not feature any special staging effects, but it did contain engaging performances. The lovers Don Juan and Donna Anna were played by young and already known actors: Bohdan Stupka and Ada Rohovtseva. They hailed from the theatre, although Stupka had played a starring role as Orest Zvonar in Yurii Illienko's film Bilyi ptakh z chornoiu oznakoiu (1970; The White Bird Marked with Black).

The role of Donna Anna emerged as the real cinematic success story of the film. Rohovtseva convincingly showed the personal catastrophe of her heroine, who seemed to be stepping firmly towards her life's triumph. She drags her freedom-loving lover who, by betraying his bride Dolores, betrays himself, into an abyss. Dolores was played by the young actress Antonina Leftii.

Whereas Stupka and Rohovtseva chose rich and vivid hues for their characters, Leftii preferred translucent, light watercolors. We see Dolores as if through a haze. Dissatisfaction with Dolores' portrayal seems justified. Her exalted, passionate nature is not maintained to the end. Still, this role was widely considered to have been a success for the young actress.

The next film made based on Ukrainka's works was directed by Vasyl Levin and Hryhorii Koltunov at the Odesa Film Studio in 1985. The producers invited Ivar Kalnins, a superstar of 1980 s Soviet cinema, to play Don Juan. In order to emphasize the fatal doom of turning the freedom-loving Don Juan away from his nature, the actor also played the Commander, Don Gonzago.

The next attempt by Odesa filmmakers to draw from Lesia Ukrainka's legacy took place in 2001, when the director Yaroslav Lupii combined three of her philosophical dramas that were based on biblical motifs in the film Na poli krovi. Aceldama (In the Field of Blood. Aceldama). However, there was hardly any organic merging of the texts Na poli krovi (In the Field of Blood), Yohanna, zhinka Khusova (Johanna, Wife of Chuza) and Oderzhyma. The picture was fragmentary. Despite the shortcomings, though, the appeal of the legacy of the poetess to filmmakers carried a certain positive weight, paving the way for filmmakers of the future to assimilate the treasures of Ukrainian literature.

In November 2019, an announcement came out that a TV series called Pleiada (The Pleiade) about prominent figures of Ukrainian culture would be made, where considerable attention would be paid to the early career and life of Lesia Ukrainka. The following is from a Culture Radio interview with Nataliia Yakovleva, the project's author and creative producer:

This fictional series is based on historical facts. We have the courage to introduce a new subgenre, which I would call historical assumption. We are building an artistic rendering with fictional characters who did not exist at the time, and we introduce them into the environment of Pleiada. Thus, our 
fictional characters will interact with genuine historical figures throughout the 10-episode series. ${ }^{22}$

As a refined intellectual who was in love with classical art, Larysa Kosach was unimpressed by vulgar entertainments, such as the early cinema. Focus on her own work coupled with serious illness did not allow her to notice the rapid development of this visual medium and its magical transformation into high art. However, there was one person, whose views and artistic tastes were extremely close to those of Lesia Ukrainka, who admired cinema: Olha Kobylianska. She not only went to see the latest films, she also dreamed of transferring her works to the screen, specifically $U$ nediliu rano zillia zbyrala (On Sunday Morning She Gathered Herbs). The writer hoped to interest German filmmakers in her work, and she even had some of it translated into German.

Kobylianska closely followed the career of Danish actress Asta Nielsen, one of the earliest stars of the silent era. As Kobylianska testified in her letters, she wrote her novel Za sytuatsiiamy (Behind the Situations) "under the influence of a great dramatic actress, who now performs, if she is still alive, only in the cinema, she being Asta Nielsen. The work should be dedicated to her." ${ }^{23}$

The female figures created on screen by Nielsen were close not only to Kobylianska's heroines, but also to Lesia Ukrainka's, like those in Blakytna troianda, with tragic feelings tormenting the soul of a young woman. We think that Lesia Ukrainka would not have overlooked the work of the Danish actress, who managed to convey the complexity and versatility of her characters through the new screen art, had she known about her. As for Olha Kobylianska, she kept a framed photograph of Asta Nielsen on her desk up until her death.

Times pass, but the artistic heritage left to the world by the Ukrainian poetess and intellectual, still largely remains to be adapted to the screen. There is hope that Ukrainian filmmakers will finally dare to approach the poetic images and philosophical depths of Lesia Ukrainka's works.

\section{(2)}

Prof. Dr. Oksana S. Moussienko, cinema historian and critic. Professor Moussienko has taught at the Kyiv National I. K. Karpenko-Kary Theater, Cinema, and Television University for nearly five decades. She was Chair of the Cinema Studies Department from 1991 to 2013. Professor Moussienko is currently a Corresponding Member of the National Academy of Arts of Ukraine. She is the author of numerous books and articles on cinema - notably: Modernism and the Avant-Garde: The Unity of Opposites (2018), Cinema of the the 2oth Century (2018), Ukrainian Cinema: Texts and Contexts (2009), Innovative Trends in French Cinema. First Half of the 2oth Century (2005), Distant Starlight: A Century of Cinema

22 Proekt Pleiada, "Na ekranah pokazhut serial pro ukrainskykh khipsteriv."

23 Rostslav Pylypchuk, "Olha Kobylianska i kinomystetstvo [Olha Kobylianska and Cinema]," Mystetstvo ekrana 1 (2001): 24. 
(co-authored by Natalia Moussienko and Valentyna Slobodian, 1995), The Screen Image of a Motherland Defender (1975). She is an Honored Artist of Ukraine and was awarded the Order of Princess Olha, the Gold Medal of the National Academy of Arts of Ukraine, and other numerous honors.

Dr. Natalia Moussienko is currently a Leading Research Fellow at the Modern Art Research Institute of the National Academy of Arts of Ukraine in Kyiv. She studied philosophy at Taras Shevchenko National University of Kyiv and subsequently at the National Academy of Sciences of Ukraine. Doctor Moussienko is the author of books and articles on art history, cultural diplomacy, and cinema-notably: Art of the Maidan (2016), Kyiv Art Space (2013), Arts and Politics (2002), and Distant Starlight: A Century of Cinema (co-authored by Oksana Moussienko and Valentyna Slobodian, 1995). She is an Honored Artist of Ukraine and was awarded the Gold Medal of the National Academy of Arts of Ukraine

Dr. Oksana O. Moussienko is a Senior Lecturer at the Kyiv National I. K. Karpenko-Kary Theater, Cinema, and Television University. She studied arts and ecomomics at Concordia University, Montreal (BA and MA), and recieved her PhD in art theory at the Institute for Art Studies, Folklore, and Ethnology at the National Academy of Sciences of Ukraine. Doctor Moussienko is author of almost twenty articles dealing with the history of cinema. 